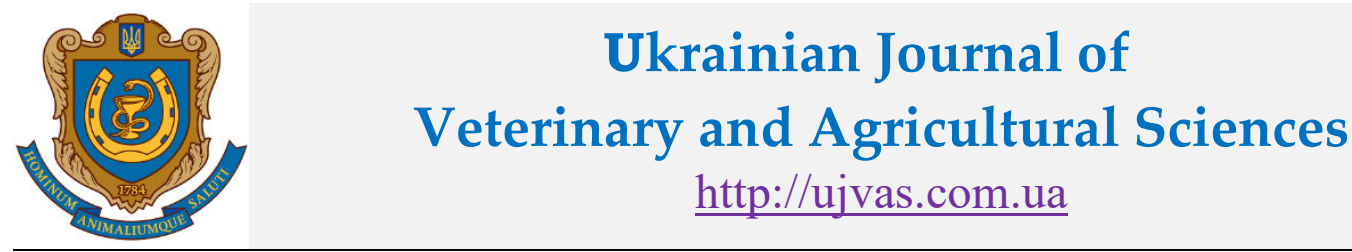

Stepan Gzhytskyi National University of Veterinary Medicine and Biotechnologies Lviv

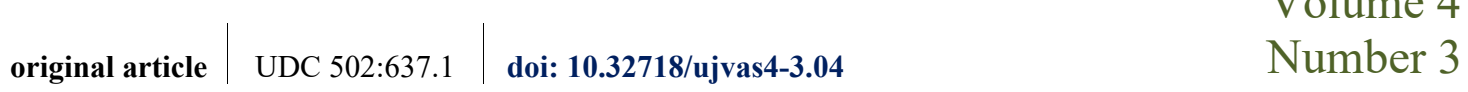

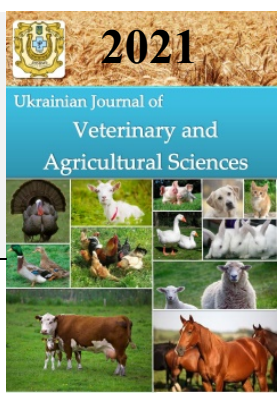

\title{
The influence of global warming on the productivity and quality of cow's milk
}

\author{
O. O. Borshch
}

Bila Tserkva National Agrarian University, pl. Soborna, 8/1, Bila Tserkva 09117, Ukraine

\begin{tabular}{l} 
Article info \\
Received 07.07.2021 \\
Received in revised form \\
12.08 .2021 \\
Accepted 13.08.2021 \\
\hline Correspondence author \\
OleksandrBorshch \\
Tel.: +380994770982 \\
E-mail: borshcha@outlook.com \\
\hline
\end{tabular}

E-mail:borshcha@outlook.com

2021 Borshch O. This is an openaccess article distributed under the terms of the Creative Commons Attribution License, which permits unrestricted use, distribution, and reproduction in any medium, provided the original author and source are credited.

\section{(cc) $\mathrm{BY}$}

\section{Contents}

1. Introduction

2. Materials and m........... 22

3. Results and discussion ........ 23

4. Conclusions ............. 26

References .................... 26

\begin{abstract}
The objective of this research was to analyze the dynamics of productivity, quality composition and energy value of cow's milk obtained during three periods (3 years each) in central Ukraine by various technological housing variants. Over the last 20 years, there has been a global trend towards of increasing in the average annual temperature, which is especially felt in winter and affects to the cattle body, their productivity and the energy value of milk. To more effectively overcome the consequences of changing weather conditions, various continentallyachieved spatial composition and types of facility for livestock housing are used, the impact of which is not sufficiently studied. We analyzed the main weather indicators for the last decade in the central part of the ForestSteppe of Ukraine (Kyiv region). The time period from 2011 to 2019 was conditionally divided into three periods (3 years each): I moderate, whose main weather indicators corresponded to the average long-term (30 years) values inherent in this natural and climatic zone; II (with a deviation of $+0.6{ }^{\circ} \mathrm{C}$ from normal values) and III (with a deviation of $+0.9{ }^{\circ} \mathrm{C}$ from normal values). During cubicle housing in low cost facilities was observed that productivity increased by 0.19 and $0.97 \mathrm{~kg}$ in II and III periods compared to I. During cubicle housing in facilities with insulation systems productivity gradually increased by $0.47 \mathrm{~kg}$ during II periods and by $0.92 \mathrm{~kg}$ during III periods. The most uniform productivity indicators were observed by housing on a deep litter among low cost facilities. Thus, productivity increased by $0.24 \mathrm{~kg}$ during II periods period, and in III period it increased by $0.47 \mathrm{~kg}$ compared to the I period. The dynamics of average daily productivity have a slightly more uniform by housing in capital facilities compared to low cost facilities. During tie housing productivity increased by $0.18 \mathrm{~kg}$ in II periods, and in III periods it increased by $0.32 \mathrm{~kg}$. Productivity increased by 0.19 and $0.43 \mathrm{~kg}$ in reconstructed capital facilities during II and III periods.
\end{abstract}

Keywords: weather, temperature rise, milk, productivity, energy value.

\section{Citation:}

Borshch, O. O. (2021). The influence of global warming on the productivity and quality of cow's milk. Ukrainian Journal of Veterinary and Agricultural Sciences, 4(3), 22-27.

\section{Introduction}

In the last decade, the trend towards global warming has continued, which is already significantly felt at the regional and local levels (WMO, 2017). For European countries, temperatures are projected to rise in all seasons in the next decade (Kjellström et al., 2018). Regional climate models predict severe warming in most northeastern Europe, particularly in winter and in southern and southwestern Europe in summer (Hempel et al., 2019). Along with an increase in the average annual temperature, the indicators of relative humidity, amount of precipitation, and the direction and strength of the wind change. Seasonal shifts and changes in the frequency and intensity of weather indicators affect most economic phenomena in the agricultural sector (Nardone et al., 2010). Agricultural sectors such as crop production, animal husbandry, fisheries, aquaculture, and forestry are expected to account for approximately $26 \%$ of all damage and losses related to climate and weather disasters (FAO, 2017). So far, much research on the impact of climate change on agricultural production has focused mainly on land use or crop yield rates (Dosio et al., 2016; Borshch et al., 2017).

The impact of climate change on livestock production is becoming increasingly urgent and relevant (Angrecka \& Herbut, 2015; Borshch et al., 2021a; Borshch et al., 2021b). Unfavorable climatic conditions for farm animals lead to deterioration of health, growth, and development, reduced productivity and product quality, reproductive characteristics, the metabolic state of animals, and their resistance (Ruban et al., 2017; Ruban et al., 2020). The term climatic stress (i.e., heat stress and cold stress) refers to the metabolic changes in farm animals when trying to adapt to changing meteorological conditions. This includes physiological and behavioral changes (Borshch et al., 2019; Borshch et al., 2020a). This can be caused by various combinations of airspeed, temperature, humidity, atmospheric pressure, and insolation (Silanikove \& Koluman, 2015). 
The effects of cold temperatures on the body have mainly been studied in cattle or dairy cows under year-round pasture conditions. However, low temperatures also have a negative impact on the cows' bodies by housing in the facility. Cold weather affects the physiological characteristics and behavior of cattle (Vitt et al., 2017). The sympathetic nervous system triggers three main physiological responses to cold stress: the first is increased metabolic heat production, the second is increased heart rate, and the third is free fatty acids mobilization for metabolism (Graunke et al., 2011; Fodor et al., 2018). During cold periods, cows increased their metabolic activity to release heat to maintain their body temperature. As a result, the energy requirement for basic metabolism increases, and accordingly to the amount of energy for other processes, such as milk production and sexual activity, are reduced (Galan et al., 2018).

One of the main measures that improve animals' welfare in stressful climatic conditions is to improve the conditions of animals' housing at different times of the year. The importance of overcoming climatic stress and its consequences have various planning, structural and technical solutions of premises and facilities for cattle housing. The use of light curtains (with elements of insulation in winter), ventilation light ridge, open feedlots with shelters, irrigation and ventilation systems, dualchamber waterbeds for cow rest, facilities with crossventilation systems, and sandwich roofs panel reduce climatic stress and allow to stabilize the cow's productivity and increase the duration of their resting time (Vitt et al., 2017).

This research aimed to analyze the dynamics of productivity, quality composition, and energy value of cow's milk obtained during three periods (3 years each) in central Ukraine by various technological housing variants.

\section{Materials and methods}

Kyiv region of Ukraine is located in the temperate zone and belongs to the central part of the forest-steppe natural and climatic zone. The climate is continental with four distinct seasons. The winter weather varies from an average daily temperature of +4 to $-18{ }^{\circ} \mathrm{C}$. This range is due to frequent changes in the types of air masses. Tropical air masses provide warm and dry weather in winter, while arctic air masses provide prolonged low temperatures, sometimes with significant precipitation in the form of snow. We analyzed the main weather indicators for the last decade in the central part of the Forest-Steppe of Ukraine (Kyiv region). The time period from 2011 to 2019 was conditionally divided into three periods (3 years each): I moderate, whose main weather indicators corresponded to the average long-term (30 years) values inherent in this natural and climatic zone; II (with a deviation of $+0.6{ }^{\circ} \mathrm{C}$ from normal values) and III (with a deviation of $+0.9{ }^{\circ} \mathrm{C}$ from normal values).

The material for research were farms selected in Bila Tserkva districts of Kyiv region with various planning solutions and variants for cows housing: low-cost facility by cubicle housing, low-cost facility with elements of heat insulation of side curtain systems by cubicle housing, lowcost facility on deep litter housing, capital brick facilities by tie housing and capital reconstructed by loose box housing.

The research was conducted on all dairy cows of farms. The farms housed Holstein cows, Ukrainian black-spotted and red-spotted breeds. The average monthly and annual productivity indicators per herd were recorded based on the results of milk yield accounting. Indicators of the mass fat fraction, protein, and lactose were determined from the average monthly data.

The net energy content (NEL) of milk was estimated by means of the following equation, derived from that proposed by the NRC (Nutrient Requirements of Dairy Cattle) (NRC, 2001):

$N E L\left(\frac{M c a l}{k g}\right)=0.0929 \times f a t, \%+0.0547 \times$ protein $_{,} \%+0.0395 \times$ lactose,$\%$,

where NEL is the gross energy of one $\mathrm{kg}$ of milk.

The NEL values obtained were converted to $\mathrm{MJ} \mathrm{kg}^{-1}$.

Indicators of the average daily air temperature were determined according to the Ukrainian hydrometeorological center. The equivalent quantity of electricity was calculated by dividing the energy value of milk by the transfer coefficient of $12 \mathrm{MJ}$ and the quantity of liquid fuel by 79.5 MJ (Pol'ova, 2013).

The obtained data were statistically processed using Statistica 11.0 software. The Student's $t$-test was used to estimate the statistical significance of the obtained values. We considered our data were marginally significant, significant, and highly significant as $\mathrm{P}<0.05,0.01$, and 0.001 .

\section{Results and discussion}

Along with the genetic and phenotypic features of cattle breeding, weather conditions are also important, the influence of which is directly related to housing and determines further productive, reproductive and bioenergetic characteristics of animals. Therefore, it is important to study productivity, quality composition and energy value of milk, depending on weather conditions in different seasons.

According to Table 1, the relationship between the average daily productivity of cows, the method of housing and the air temperature is traced. During cubicle housing in low cost facilities was observed that productivity increased by 0.19 and $0.97 \mathrm{~kg}$ in II and III periods compared to I. During cubicle housing in facilities with insulation systems productivity gradually increased by $0.47 \mathrm{~kg}$ during II periods and by $0.92 \mathrm{~kg}$ during III periods. The most uniform productivity indicators were observed by housing on a deep litter among low cost facilities. Thus, productivity increased by $0.24 \mathrm{~kg}$ during II periods period, and in III period it increased by $0.47 \mathrm{~kg}$ compared to the I period. The dynamics of average daily productivity have a slightly more uniform by housing in capital facilities compared to low cost facilities. During tie housing productivity increased by $0.18 \mathrm{~kg}$ in II periods, and in III periods it increased by $0.32 \mathrm{~kg}$. Productivity increased by 0.19 and $0.43 \mathrm{~kg}$ in reconstructed capital facilities during II and III periods. 
Table 1

The average daily productivity during during research periods, $\mathrm{kg} / \mathrm{head}$

\begin{tabular}{|c|c|c|c|}
\hline \multirow[b]{2}{*}{$\begin{array}{l}\text { Type of facilities and housing } \\
\text { variants }\end{array}$} & \multicolumn{3}{|c|}{ Weather periods } \\
\hline & $\mathrm{I}$ & $\begin{array}{c}\text { II } \\
\left(+0.6^{\circ} \mathrm{C} \text { from normal values }\right)\end{array}$ & $\begin{array}{c}\text { III } \\
\left(+0.9^{\circ} \mathrm{C} \text { from normal values }\right)\end{array}$ \\
\hline $\begin{array}{l}\text { Low cost facilities: } \\
\text { - cubicle housing }(n=421)\end{array}$ & $26.57 \pm 0.16$ & $26.76 \pm 0.18$ & $27.54 \pm 0.18^{* * *}$ \\
\hline $\begin{array}{l}\text { - cubicle housing with insulation } \\
\text { systems }(n=297)\end{array}$ & $26.82 \pm 0.15$ & $27.29 \pm 0.12^{*}$ & $27.74 \pm 0.09^{* * *}$ \\
\hline - on a deep straw litter $(n=434)$ & $22.55 \pm 0.26$ & $22.79 \pm 0.29$ & $23.02 \pm 0.32$ \\
\hline $\begin{array}{l}\text { Capital facilities: } \\
\text { - tie housing }(\mathrm{n}=82)\end{array}$ & $21.64 \pm 0.09$ & $21.82 \pm 0.09$ & $21.96 \pm 0.13^{*}$ \\
\hline $\begin{array}{l}\text { - reconstructed facilitiesy for } \\
\text { loose housing }(\mathrm{n}=78)\end{array}$ & $22.45 \pm 0.13$ & $22.64 \pm 0.14^{*}$ & $22.88 \pm 0.14^{*}$ \\
\hline
\end{tabular}

Notes: ${ }^{*} \mathrm{P}<0.05 ;{ }^{* *} \mathrm{P}<0.01 ;{ }^{* * *} \mathrm{P}<0.001$ as compared with I period

It is established that the use of air temperature cooling and insulation of the premises affected the content of mass fraction of fat in milk (table. 2). A decrease in the mass fraction of fat in milk was observed from $3.96 \%$ in I period to $3.94 \%$ and $3.93 \%$ in II and III ones by cubicle housing. When boxing cows in easily assembled premises with cooling elements, an increase in the mass fraction of fat in milk was observed from $3.96 \%$ in the first period to $3.98 \%$ in the third period.The indicator of milk fat synthesis increased by 8.24 and $48.10 \mathrm{~kg} / \mathrm{head}$ during II and III periods. During boxing in rooms with insulation systems, the mass fraction of fat in cow's milk increased in the II and III periods (by 0.06 and $0.09 \%$ ), and fat synthesis increased by 38.41 and $67.43 \mathrm{~kg} / \mathrm{head}$, respectively, compared to I period. When cows were kept in deep straw litter, the mass fraction of fat in milk gradually decreased - from $4.20 \%$ in the first period to $4.18 \%$ in the third period. The synthesis of milk fat increased by 8.54 and $16.57 \mathrm{~kg} / \mathrm{head}$. When keeping cows in capital premises on a leash and in the period from april to october on feedlots without shades, the fat content in milk decreased by 0.02 and $0.03 \%$ in the II and III periods, and fat synthesis increased by 7.85 and $11.35 \mathrm{~kg} /$ head compared to the I period. As for the option of keeping cows in a capital room reconstructed for loose housing and in the period from april to october on feedlot with shades, in this combination during the experimental periods, the mass fraction of fat in milk was at the same level. The yield of milk fat increased in the II and III periods by 8.07 and $18.26 \mathrm{~kg} /$ head compared to the I period.

Table 2

The average mass fraction of fat in cow's milk (\%) and its synthesis during research periods, $\mathrm{kg} / \mathrm{head}$

\begin{tabular}{|c|c|c|c|c|c|c|}
\hline \multirow{3}{*}{$\begin{array}{c}\text { Type of facilities and housing } \\
\text { variants }\end{array}$} & \multicolumn{6}{|c|}{ Weather periods } \\
\hline & \multicolumn{2}{|r|}{ I } & \multicolumn{2}{|c|}{$\begin{array}{c}\text { II } \\
\left(+0.6^{\circ} \mathrm{C} \text { from normal values }\right)\end{array}$} & \multicolumn{2}{|c|}{$\begin{array}{c}\text { III } \\
\left(+0.9^{\circ} \mathrm{C} \text { from normal values }\right)\end{array}$} \\
\hline & $\%$ fat & fat synthesis & $\%$ fat & fat synthesis & $\%$ fat & fat synthesis \\
\hline $\begin{array}{l}\text { Low cost facilities: } \\
\text { - cubicle housing }(\mathrm{n}=421)\end{array}$ & $3.96 \pm 0.02$ & $1152.12 \pm 6.94$ & $3.96 \pm 0.01$ & $1160.36 \pm 8.03$ & $3.98 \pm 0.02$ & $1200.22 \pm 10.04^{* * *}$ \\
\hline $\begin{array}{l}\text { - cubicle housing with } \\
\text { insulation systems }(n=297)\end{array}$ & $3.98 \pm 0.02$ & $1168.84 \pm 10.88$ & $4.04 \pm 0.03$ & $1207.25 \pm 11.94^{*}$ & $4.07 \pm 0.03^{*}$ & $1236.27 \pm 11.93^{* * *}$ \\
\hline $\begin{array}{l}\text { - on a deep straw litter } \\
(\mathrm{n}=434)\end{array}$ & $4.20 \pm 0.07$ & $1037.07 \pm 5.89$ & $4.19 \pm 0.07$ & $1045.61 \pm 6.90$ & $4.18 \pm 0.06$ & $1053.64 \pm 6.94$ \\
\hline $\begin{array}{l}\text { Capital facilities: } \\
\text { - tie housing }(n=82)\end{array}$ & $3.87 \pm 0.03$ & $912.02 \pm 6.65$ & $3.85 \pm 0.03$ & $919.87 \pm 7.70$ & $3.84 \pm 0.02$ & $923.37 \pm 6.74$ \\
\hline $\begin{array}{l}\text { - reconstructed facilitiesy for } \\
\text { loose housing }(\mathrm{n}=78)\end{array}$ & $3.88 \pm 0.04$ & $953.81 \pm 9.59$ & $3.88 \pm 0.04$ & $961.88 \pm 8.64$ & $3.88 \pm 0.03$ & $972.07 \pm 10.06$ \\
\hline
\end{tabular}

Notes: ${ }^{*} \mathrm{P}<0.05 ;{ }^{* *} \mathrm{P}<0.01 ;{ }^{* * *} \mathrm{P}<0.001$ as compared with with I period

There was a tendency to reduce the mass fraction of protein in milk by all housing variants during II and III periods compared to I period (table 3). The maximum decrease in the mass fraction of protein was $0.02 \%$ by cubicle housing in low cost housing facilities and on deep litter and in capital facilities by tie housing, in compared to the I period. The decrease in the mass fraction of protein was $0.01 \%$ by cubicle housing with insulation systems and in reconstructed capital facility. Concerning that milk protein synthesis gradually increased by all housing variants in II and III periods. Milk protein synthesis increased by 3.79 and $28.27 \mathrm{~kg} / \mathrm{head}$ for cubicle housing with insulation elements. Smallest increase in the mass fraction of protein in cow's milk was observed by housing on a deep litter in compared to the other housing variants in low cost facilities. Thus, protein synthesis increased by $8.80 \mathrm{~kg} / \mathrm{h}$ ead during II period, and during III period by $12.20 \mathrm{~kg} / \mathrm{head}$ compared to I period.

Protein synthesis in cow's milk increased by 1.63 and $3.42 \mathrm{~kg} /$ head by tie housing in capital facilities, and by 4.24 and $12.70 \mathrm{~kg} /$ head in reconstructed facilities by loose housing.

The mass fraction of lactose in cow's milk decreased by 0.01 or $0.02 \%$ by all housing variants during II and III period, compared to I period (table 4). Only by loose cows housing in capital reconstructed facilities, the dynamics of lactose level in their milk was reversed, and during III period the mass fraction of lactose was $0.01 \%$ higher than 
in I and II periods. Lactose synthesis increased by 6.30 and $41.12 \mathrm{~kg} /$ head for cows housing in low cost facilities, and by 22.85 and $41.69 \mathrm{~kg}$ for cows housing in low cost facilities with insulation systems during II and III periods, compared to I period. Lactose synthesis increased by 8.86 and
$20.02 \mathrm{~kg} /$ head for cattle housing on deep litter in compared to I period. During this period, an increase the lactose synthesis was also observed by 6.26 and $12.98 \mathrm{~kg} /$ head for tie housing in capital facilities, and in compared to I period by 9.20 and $23.32 \mathrm{~kg} /$ head for loose housing.

Table 3

The average mass fraction of protein in cow's milk (\%) and its synthesis during research period, $\mathrm{kg} / \mathrm{head}$

\begin{tabular}{|c|c|c|c|c|c|c|}
\hline \multirow{3}{*}{$\begin{array}{c}\text { Type of facilities and housing } \\
\text { variants }\end{array}$} & \multicolumn{6}{|c|}{ Weather periods } \\
\hline & \multicolumn{2}{|r|}{$\mathrm{I}$} & \multicolumn{2}{|c|}{$\begin{array}{c}\text { II } \\
\left(+0.6^{\circ} \mathrm{C} \text { from normal values }\right) \\
\end{array}$} & \multicolumn{2}{|c|}{$\begin{array}{c}\text { III } \\
\left(+0.9^{\circ} \mathrm{C} \text { from normal values }\right)\end{array}$} \\
\hline & $\%$ protein & $\begin{array}{l}\text { protein syn- } \\
\text { thesis }\end{array}$ & $\%$ protein & protein synthesis & $\%$ protein & protein synthesis \\
\hline $\begin{array}{l}\text { Low cost facilities: } \\
\text { - cubicle housing }(n=421)\end{array}$ & $3.23 \pm 0.005$ & $939.74 \pm 6.77$ & $3.22 \pm 0.005$ & $943.53 \pm 7.79$ & $3.21 \pm 0.004$ & $968.01 \pm 8.12^{* *}$ \\
\hline $\begin{array}{l}\text { - cubicle housing with insulation } \\
\text { systems }(\mathrm{n}=297)\end{array}$ & $3.25 \pm 0.005$ & $954.45 \pm 5.89$ & $3.24 \pm 0.004$ & $968.19 \pm 6.78$ & $3.24 \pm 0.004$ & $984.16 \pm 7.88^{* *}$ \\
\hline - on a deep straw litter $(n=434)$ & $3.35=$ & $827.19 \pm 3.62$ & $3.35 \pm 0.007$ & $835.99 \pm 3.58$ & $3.33 \pm 0.007$ & $839.39 \pm 3.61^{*}$ \\
\hline $\begin{array}{l}\text { Capital facilities: } \\
\text { - tie housing }(\mathrm{n}=82)\end{array}$ & $3.25 \pm 0.004$ & $770.11 \pm 4.61$ & $3.23 \pm 0.003$ & $771.74 \pm 4.64$ & $3.23 \pm 0.003$ & $766.69 \pm 4.52$ \\
\hline $\begin{array}{l}\text { - reconstructed facilitiesy for loose } \\
\text { housing }(\mathrm{n}=78)\end{array}$ & $3.23 \pm 0.008$ & $794.02 \pm 5.52$ & $3.22 \pm 0.008$ & $798.26 \pm 5.48$ & $3.22 \pm 0.007$ & $806.72 \pm 5.50$ \\
\hline
\end{tabular}

Notes: ${ }^{* *} \mathrm{P}<0.01$ as compared with with with I period

Table 4

The average mass fraction of lactose in cow's milk (\%) and its synthesis for research period, $\mathrm{kg} / \mathrm{head}$

\begin{tabular}{|c|c|c|c|c|c|c|}
\hline \multirow{3}{*}{$\begin{array}{c}\text { Type of facilities and housing } \\
\text { variants }\end{array}$} & \multicolumn{6}{|c|}{ Weather periods } \\
\hline & \multicolumn{2}{|r|}{ I } & \multicolumn{2}{|c|}{$\begin{array}{c}\text { II } \\
\left(+0.6^{\circ} \mathrm{C} \text { from normal values }\right)\end{array}$} & \multicolumn{2}{|c|}{$\begin{array}{c}\text { III } \\
\left(+0.9^{\circ} \mathrm{C} \text { from normal values }\right)\end{array}$} \\
\hline & $\%$ lactose & lactose synthesis & $\%$ lactose & lactose synthesis & $\%$ lactose & lactose synthesis \\
\hline $\begin{array}{l}\text { Low cost facilities: } \\
\text { - cubicle housing }(n=421)\end{array}$ & $4.44 \pm 0.010$ & $1291.78 \pm 14.01$ & $4.43 \pm 0.009$ & $1298.08 \pm 12.33$ & $4.42 \pm 0.007$ & $1332.90 \pm 15.06^{*}$ \\
\hline $\begin{array}{l}\text { - cubicle housing with insulation } \\
\text { systems }(\mathrm{n}=297)\end{array}$ & $4.44 \pm 0.014$ & $1303.93 \pm 10.90$ & $4.44 \pm 0.014$ & $1326.78 \pm 11.93^{*}$ & $4.43 \pm 0.015$ & $1345.62 \pm 12.07^{*}$ \\
\hline - on a deep straw litter $(n=434)$ & $4.51 \pm 0.003$ & $1114.11 \pm 8.33$ & $4.50 \pm 0.003$ & $1122.97 \pm 8.04$ & $4.50 \pm 0.004$ & $1134.31 \pm 8.58$ \\
\hline $\begin{array}{l}\text { Capital facilities: } \\
\text { - tie housing }(n=82)\end{array}$ & $4.39 \pm 0.006$ & $1040.24 \pm 7.89$ & $4.38 \pm 0.005$ & $1046.50 \pm 7.92$ & $4.38 \pm 0.005$ & $1053.22 \pm 7.96$ \\
\hline $\begin{array}{l}\text { - reconstructed facilitiesy for loose } \\
\text { housing }(\mathrm{n}=78)\end{array}$ & $4.42 \pm 0.003$ & $1086.55 \pm 7.75$ & $4.42 \pm 0.003$ & $1095.75 \pm 8.16$ & $4.43 \pm 0.004$ & $1109.87 \pm 8.85^{*}$ \\
\hline
\end{tabular}

Notes: ${ }^{*} \mathrm{P}<0.05 ;{ }^{* *} \mathrm{P}<0.01 ;{ }^{* * *} \mathrm{P}<0.001$ as compared with I period

When keeping cows in an easy-to-assemble room with insulation elements, the energy value of $1 \mathrm{~kg}$ of milk increased in periods II and III by 0.025 and $0.035 \mathrm{MJ}$, respectively (Table 5). However, a decrease in the energy value of $1 \mathrm{~kg}$ of milk (by 0.04 and $0.012 \mathrm{MJ}$ ) was observed when kept indoors on a deep litter. With tethered cows in the capital room, the energy value of $1 \mathrm{~kg}$ of milk decreased in the II and III periods - by 0,13 and $0.17 \mathrm{MJ}$, respectively. In the case of loose housing of cows in the reconstructed premises, a slight increase (by $0.02 \mathrm{MJ}$ ) was observed in the third period. In all studied farms there was a tendency to increase the EC daily milk yield in the II and III periods.

\section{Table 5}

The average energy value $(\mathrm{EV})$ of $1 \mathrm{~kg}$ of milk and milk yield/head in winter period, $\mathrm{MJ}$

\begin{tabular}{|c|c|c|c|c|}
\hline \multirow{3}{*}{$\begin{array}{l}\text { Type of facilities and housing } \\
\text { variants }\end{array}$} & \multicolumn{4}{|c|}{ Weather periods } \\
\hline & I & $\begin{array}{c}\text { II } \\
\left(+0.6^{\circ} \mathrm{C} \text { from normal values }\right)\end{array}$ & \multicolumn{2}{|c|}{$\begin{array}{c}\text { III } \\
\left(+0.9^{\circ} \mathrm{C} \text { from normal values }\right)\end{array}$} \\
\hline & $\begin{array}{l}\text { EV of } 1 \mathrm{~kg} \text { of } \\
\text { milk }\end{array}$ & $\begin{array}{cc}\begin{array}{c}\text { EV of } 1 \mathrm{~kg} \text { of } \\
\text { milk }\end{array} & \begin{array}{c}\text { EV of milk } \\
\text { yield }\end{array} \\
\end{array}$ & $\begin{array}{l}\text { EV of } 1 \mathrm{~kg} \text { of } \\
\text { milk }\end{array}$ & $\begin{array}{c}\text { EV of milk } \\
\text { yield }\end{array}$ \\
\hline $\begin{array}{l}\text { Low cost facilities: } \\
\text { - cubicle housing }(n=421)\end{array}$ & $3.014 \pm 0.001380 .08 \pm 4.37$ & $3.010 \pm 0.001380 .54 \pm 4.55$ & $3.014 \pm 0.0012$ & $83.01 \pm 4.72$ \\
\hline $\begin{array}{l}\text { - cubicle housing with insulation } \\
\text { systems }(n=297)\end{array}$ & $3.023 \pm 0.001081 .07 \pm 3.70$ & $3.048 \pm 0.001283 .17 \pm 4.13$ & $3.058 \pm 0.0010$ & $84.82 \pm 4.57$ \\
\hline - on a deep straw litter $(n=434)$ & $3.144 \pm 0.001570,89 \pm 3,07$ & $3.140 \pm 0.001771 .56 \pm 4.06$ & $3.132 \pm 0.0015$ & $72.09 \pm 3.95$ \\
\hline $\begin{array}{l}\text { Capital facilities: } \\
\text { - tie housing }(\mathrm{n}=82)\end{array}$ & $2.973 \pm 0.001464,33 \pm 2,25$ & $2.960 \pm 0.001264 .58 \pm 2.25$ & $2.956 \pm 0.0012$ & $64.91 \pm 2.20$ \\
\hline $\begin{array}{l}\text { - reconstructed facilitiesy for loose } \\
\text { housing }(\mathrm{n}=78)\end{array}$ & $2.977 \pm 0.001366 .83 \pm 2.03$ & $2.977 \pm 0.001267 .40 \pm 2.28$ & $2.979 \pm 0.0012$ & $68.16 \pm 2.41$ \\
\hline
\end{tabular}

Notes: ${ }^{*} \mathrm{P}<0.05 ;{ }^{* *} \mathrm{P}<0.01 ;{ }^{* * *} \mathrm{P}<0.001$ as compared with with I period 
An increase the energy value of milk in recalculation on fuel energy and electricity was observed by all housing variants (table 6). At the same time, the highest growth rates of the energy value of milk in recalculation on fuel energy and electricity during II and III periods were by cubicle housing, and the lowest by tie housing in capital facilities.

Table 6

The energy value of milk in recalculation on fuel energy (L) and electricity (kWh) per 1 head

\begin{tabular}{|c|c|c|c|c|c|}
\hline \multirow{4}{*}{$\begin{array}{l}\text { Type of facilities and housing } \\
\text { variants }\end{array}$} & \multicolumn{5}{|c|}{ Weather periods } \\
\hline & I & \multicolumn{2}{|c|}{$\begin{array}{c}\text { II } \\
\left(+0.6^{\circ} \mathrm{C} \text { from normal values }\right)\end{array}$} & \multicolumn{2}{|c|}{$\begin{array}{c}\text { III } \\
\left(+0.9^{\circ} \mathrm{C} \text { from normal values }\right)\end{array}$} \\
\hline & \multicolumn{5}{|c|}{ The energy value of milk in recalculation on electricity $(\mathrm{kWh})$} \\
\hline & $\begin{array}{c}\text { on average per I } \\
\text { period }\end{array}$ & $\begin{array}{c}\text { on average per II } \\
\text { period }\end{array}$ & \pm with I period & $\begin{array}{l}\text { on average per III } \\
\text { period }\end{array}$ & \pm with I period \\
\hline $\begin{array}{l}\text { Low cost facilities: } \\
\text { - cubicle housing }(n=421)\end{array}$ & 7307.3 & 7349.3 & +42.0 & 7574.6 & +267.3 \\
\hline $\begin{array}{l}\text { - cubicle housing with insulation } \\
\text { systems }(n=297)\end{array}$ & 7397.6 & 7589.2 & +191.6 & 7739.8 & +342.2 \\
\hline - on a deep straw litter $(n=434)$ & 6469.3 & 6529.8 & +60.5 & 6578.2 & +108.9 \\
\hline $\begin{array}{l}\text { Capital facilities: } \\
\text { - tie housing }(n=82)\end{array}$ & 5870.1 & 5892.9 & +12.80 & 5923.0 & +52.9 \\
\hline $\begin{array}{l}\text { - reconstructed facilitiesy for } \\
\text { loose housing }(\mathrm{n}=78)\end{array}$ & 6098.2 & 6150.2 & +52.0 & 6219.6 & +121.4 \\
\hline \multicolumn{6}{|c|}{ The energy value of milk in recalculation on fuel energy (L) } \\
\hline $\begin{array}{l}\text { Low cost facilities: } \\
\text { - cubicle housing }(n=421)\end{array}$ & 1102.9 & 1109.3 & +6.4 & 1143.3 & +40.4 \\
\hline $\begin{array}{l}\text { - cubicle housing with insulation } \\
\text { systems }(\mathrm{n}=297)\end{array}$ & 1116,6 & 1145.5 & +28.9 & 1168.3 & +51.7 \\
\hline - on a deep straw litter $(n=434)$ & 976.5 & 985.6 & +9.1 & 992.9 & +16.4 \\
\hline $\begin{array}{l}\text { Capital facilities: } \\
\text { - tie housing }(\mathrm{n}=82)\end{array}$ & 886.0 & 889.5 & +3.5 & 894.0 & +8.0 \\
\hline $\begin{array}{l}\text { - reconstructed facilitiesy for } \\
\text { loose housing }(\mathrm{n}=78)\end{array}$ & 920.5 & 928.3 & +7.8 & 938.8 & +18.3 \\
\hline
\end{tabular}

\section{Conclusions}

Thus, the increase in average annual air temperature values affected the indicators of productivity, quality composition and energy value of milk for all options for keeping cows. The productivity of cows in all variants of keeping in the first period was lower, and the indicators of protein and lactose content tended to increase compared to the second and third periods. At the same time, in the II and III periods, an increase in the synthesis of fat, protein and lactose and the energy value of milk was observed. The most stable performance indicators for maintenance options in prefabricated premises were in deep litter, and in capital - for loose maintenance in reconstructed premises.

\section{Conflict of interest}

Author does not report any financial or personal connections with other persons or organizations, which might negatively affect the contents of this publication and/or claim authorship rights to this publication.

\section{References}

Angrecka, S., \& Herbut, P. (2015). Conditions for cold stress development in dairy cattle kept in the free-stall barn during severe frosts. Czech Journal of Animal Science, 60, 81-87. https://doi.org/10.17221/7978-CJAS.

Borshch, A. A., Ruban, S., Borshch, A. V., \& Babenko, O. (2019). Effect of three bedding materials on the microclimate conditions, cows behavior and milk yield. Polish Journal of Natural Sciences, 34, 19-31. URL: http://rep.btsau.edu.ua/handle/ BNAU/2091.
Borshch, O. O., Borshch, O. V., Kosior, L. T., Pirova, L. V., \& Lastovska, I. O. (2017). Influence of various litter materials and premises characteristics on the comfort and behavior of cows. Ukrainian Journal of Ecology, 7(4), 529-535. DOI: $10.15421 / 2017156$.

Borshch, O. O., Ruban, S. Yu., Gutyj, B. V., Borshch, O. V., Sobolev, O. I., Kosior, L. T., Fedorchenko, M. M., Kirii, A. A., Pivtorak, Y. I., Salamakha, I. Yu., Hordiichuk, N. M., Hordiichuk, L. M., Kamratska, O. I., \& Denkovich, B. S. (2020a). Comfort and cow behavior during periods of intense precipitation. Ukrainian Journal of Ecology, 10(6), 98-102. DOI: $10.15421 / 2020265$.

Borshch, O. O., Gutyj, B. V., Borshch, O. V., Sobolev, O. I., Chernyuk, S. V., Rudenko, O. P., Kalyn, B. M., Lytvyn, N. A., Savchuk, L. B., Kit, L. P., Nahirniak, T. B., Kropyvka, S. I., \& Pundyak, T. O. (2020b). Environmental pollution is caused by the manure storage. Ukrainian Journal of Ecology, 10(3), 110 114. DOI: $10.15421 / 2020 \_142$.

Borshch, O. O., Ruban, S., \& Borshch, O. V. (2021a). Review: the influence of genotypic and phenotypic factors on the comfort and welfare rates of cows during the period of global climate changes. Agraarteadus, 32(1), 25-34. doi: 10.15159/jas.21.12.

Borshch, O. O., Borshch, O. V., Sobolev, O. I., Nadtochii, V. M., Slusar, M. V., Gutyj, B. V., Polishchuk, S. A., Malina, V. V., Korol, A. P., Korol-Bezpala, L. P., Bezpalyi, I. F., \& Cherniavskyi, O. O. (2021b). Wind speed in easily assembled premises with different design constructions for side curtains in winter. Ukrainian Journal of Ecology, 11(1), 325-328. DOI: $10.15421 / 202149$.

Dosio, A. (2016). Projections of climate change indices of temperature and precipitation from an ensemble of biasadjusted high-resolution EURO-CORDEX regional climate models. Journal of Geophysical Research: Atmospheres, 121, 5488-5511. DOI: 10.1002/2015JD024411.

Fodor, N., Foskolos, A., Topp, C. F. E, Moorby, J. M, Pasztor, L., \& Foyer, C. H. (2018). Spatially explicit estimation of heat 
stress-related impacts of climate change on the milk production of dairy cows in the United Kingdom. PLoS ONE, 13(5), e0197076. DOI: 10.1371/journal.pone.0197076.

Food and Agriculture Organization of the United Nations (FAO). The Impact of Disasters on Agriculture - Assessing the information gap. Available at: http://www.fao.org/3/ai7279e.pdf, 2017.

Galán, E., Llonch, P., Villagrá, A., Levit, H., Pinto, S., \& del Prado, A. (2018). A systematic review of nonproductivity-related animal-based indicators of heat stress resilience in dairy cattle. PLoS ONE, 13, e0206520. DOI: 10.1371/journal.pone.0206520.

Graunke, K. L., Schuster, T., \& Lidfors, L. M. (2011). Influence of weather on the behaviour of outdoor-wintered beef cattle in Scandinavia. Livestock Science, 136(2-3), 247-255. DOI: $10.1016 / j .1$ ivsci.2010.09.018.

Hempel, S., Menz, C., Pinto, S., Galan, E., Janke, D., Estellés, F., Müschner-Siemens, T., Wang, X., Heinicke, J., Zhang, G., Amon, B., del Prado, A., \& Amon, T. (2019). Heat stress risk in European dairy cattle husbandry under different climate change scenarios - uncertainties and potential impacts. Earth System Dynamics, 10, 859-884. DOI: 10.5194/esd-10-8592019.

Kjellström, E., Nikulin, G., Strandberg, G., Christensen, O. B., Jacob, D., Keuler, K., Lenderink G., van Meijgaard E., Schär C., Somot S., Sørland S.L., Teichmann C., \& Vautard, R. (2018). European climate change at global mean temperature increases of 1.5 and $2{ }^{\circ} \mathrm{C}$ above pre-industrial conditions as simulated by the EURO-CORDEX regional climate models. Earth System Dynamycs, 9, 459-478. doi: 10.5194/esd-9-459-2018.

Nardone, A., Ronchi, B., Lacetera, N., Ranieri, M. S., \& Bernabucci, U. (2010). Effects of climate changes on animal production and sustainability of livestock systems. Livestock Science, 130, 57-69. DOI: 10.1016/j.livsci.2010.02.011.
NRC (2001). Nutrient Requirements of Dairy Cattle. 7th rev. ed. National. Academy Press, 2101 Constitution Avenue, N.W., Lockbox 285, Washington, USA, 381.

Pol'ova, O. L. (2013). Application of the profit-saving ratio in dairy farming. Methodological recommendations (in Ukrainian).

Ruban, S. Yu., Borshch, O. V., \& Borshch, O. O. (2017). Suchasni tekhnolohiyi vyrobnytstva moloka. (osoblyvosti ekspluatatsiyi, tekhnolohichni rishennya, eskizni property) [Modern milk production technologies. (peculiarities of operation, technological decisions, sketch designs)]. Kharkiv: STYLIZDAT (in Ukrainian).

Ruban, S., Borshch, O. O., Borshch, O. V., Orischuk, O., Balatskiy, Y., Fedorchenko, M., Kachan, A., \& Zlochevskiy, M. (2020). The impact of high temperatures on respiration rate, breathing condition and productivity of dairy cows in different production systems. Animal Science Papers and Reports, 38(1), 61-72. URL: https://www.cabdirect.org/cabdirect/abstract/20203167447.

Silanikove, N., \& Koluman (Darcan), N. (2015). Impact of climate change on the dairy industry in temperate zones: Predications on the overall negative impact and on the positive role of dairy goats in adaptation to earth warming. Small Ruminant Research, 123, 27-34. DOI: 10.1016/j.smallrumres.2014.11.005.

Vitt, R., Weber, L., Zollitsch, W., Hörtenhuber, S. J., Baumgartner, J., Niebuhr, K., Piringer, M., Anders, I., Andre, K., HennigPauka, I., Schönhart, M., \& Schauberger, G. (2017). Modelled performance of energy saving air treatment devices to mitigate heat stress for confined livestock buildings in Central Europe. Biosystems Engineering, 164, 85-97. doi: 10.1016/j.biosystemseng.2017.09.013.

World Meteorological Organization Statement on the state of the global climate in 2017, in: WMO-No.1212, Publications Board WMO, World Meteorological Organization, Geneva, Switzerland, 2018. 